\title{
Using Phosphorus and Zeolite to Immobilize Lead in Two Contrasting Contaminated Urban Soils
}

\author{
Junhui Li ${ }^{1,2}$, Chongjian Jia', Ying Lu ${ }^{1 *}$, Hojae Shim ${ }^{3}$ \\ ${ }^{1}$ College of Natural Resources and Environmental Science, South China Agricultural University, \\ Guangzhou 510642, China \\ ${ }^{2}$ Department of Earth System Science, University of California, Irvine, CA 92697, USA \\ ${ }^{3}$ Department of Civil and Environmental Engineering, Faculty of Science and Technology, University of Macau, \\ Macau SAR 999078, China
}

Received: 27 December 2015

Accepted: 23 February 2016

\begin{abstract}
Lead $(\mathrm{Pb})$ contamination of urban soil is a threat to human health, and reducing the risk of $\mathrm{Pb}$-contaminated soil is a continuing international concern. Soil stabilization technique has been considered as a promising remediation technique to facilitate the immobilization of $\mathrm{Pb}$ in soil. The purpose of this study was to evaluate the effects of different amendments, including $\mathrm{H}_{3} \mathrm{PO}_{4}, \mathrm{Ca}\left(\mathrm{H}_{2} \mathrm{PO}_{4}\right)_{2}, \mathrm{H}_{3} \mathrm{PO}_{4}+\mathrm{Ca}\left(\mathrm{H}_{2} \mathrm{PO}_{4}\right)_{2}$, and zeolite on $\mathrm{Pb}$ levels in two naturally contaminated urban soils. $\mathrm{Pb}$ speciation and bioavailability was evaluated by the sequential extraction test (SET) and the toxicity characteristic leaching procedure (TCLP) after a two-month incubation. The application of phosphorus amendments significantly reduced the TCLP-Pb concentration in two soil types and the SET-Pb in Soil 1 (alkaline but with high Pb level), whereas the zeolite amendment diminished the SET-Pb in two soil types and the TCLP-Pb in Soil 1. Nevertheless, regardless of the soil type, the application of phosphorus amendments resulted in a significant increase of residual $\mathrm{Pb}$. These phosphate amendments may be a viable strategy in the in situ remediation of $\mathrm{Pb}$ contamination in urban soils.
\end{abstract}

Keywords: amendments, bioavailability, immobilization, $\mathrm{Pb}$, urban soils

\section{Introduction}

Heavy metal contamination of urban soils has attracted considerable attention around the world because of their toxicity and threat to human life and the environment [14]. The United Nations [5] has documented that more than half $(54 \%)$ of the world population lives in urban areas as of 2014 and the proportion is expected to increase, reaching $66 \%$ by 2050 , thereby further strengthening concern about heavy metal contamination of urban soil. Lead $(\mathrm{Pb})$, known as one of the most toxic elements to human health, can impair intellectual development in young children [6]. The potential of various amendments to reduce mobility and bioavailability of $\mathrm{Pb}$ in soils is an ongoing applied research pursuit [7].

*e-mail: luying@scau.edu.cn 
The selection of the most suitable amendments for in situ $\mathrm{Pb}$ immobilization is a key factor [8] . Henry et al. [9] demonstrated that the in situ remediation with phosphate amendments based on bioaccessibility assessments is the best approach. Phosphate (P) amendments are known to form stable $\mathrm{Pb}-\mathrm{P}$ minerals (i.e., pyromorphite) [10]. Although previous studies have addressed the effect of different forms of phosphate on the immobilization of metals, there is still limited information regarding bioaccessibility assessments of their effectiveness. Therefore, quantifying the $\mathrm{Pb}$ speciation - particularly of its bioavailable form - under the applied chemical amendments is of utmost importance in risk assessment and remediation [8]. Research is urgently needed to increase confidence in using these approaches in riskbased decision making in the context of natural urban soils [9]. In this study, we conducted batch incubation experiments with amendments $\left(\mathrm{H}_{3} \mathrm{PO}_{4}, \mathrm{Ca}\left(\mathrm{H}_{2} \mathrm{PO}_{4}\right)_{2}\right.$, $\mathrm{H}_{3} \mathrm{PO}_{4}+\mathrm{Ca}\left(\mathrm{H}_{2} \mathrm{PO}_{4}\right)_{2}$, and zeolite) in two contrasting contaminated urban soils. The objective of this study was to evaluate $\mathrm{Pb}$ immobilization effectiveness using the toxicity characteristic leaching procedure (TCLP) test and sequential extraction test (SET) following stabilization treatment.

\section{Materials and Methods}

\section{Soil Collection and Analysis}

Two soil types used in this study, representing different levels of lead, were collected from the respective steel industrial area and roadside in the urban districts of Guangzhou, China [2]. The composite soil samples collected at a depth of $0-10 \mathrm{~cm}$ were obtained by mixing subsamples from five random points within $2 \mathrm{~m}^{2}$ in each sampling site. Soil samples were air-dried, crushed to pass through a 2-mm nylon sieve, and homogenized, which were then used for the incubation experiment and determination of soil $\mathrm{pH}$ and particle size distribution.

The sub-samples were further ground with an agate grinder to go through a $0.15-\mathrm{mm}$ nylon sieve, which were then used to determine soil $\mathrm{Pb}$, soil organic matter, and total phosphorus (TP). The soil $\mathrm{Pb}$ was determined by digesting soil sample with a mixture of concentrated $\mathrm{HNO}_{3}, \mathrm{HF}$, and $\mathrm{HClO}_{4}$ in a polyvinyl-fluoride crucible, followed by graphite furnace atomic absorption spectrophotometry (GFAAS-AA800, PerkinElmer Inc.)
[11]. The recovery of analyzed $\mathrm{Pb}$ in a reference material was within $\pm 10 \%$ of the certified value, and the relative standard deviation of duplicate measurements was less than $10 \%$. Soil $\mathrm{pH}$ was measured using a 1:2.5 (w/v) ratio of soil to distilled water, the organic matter was determined using the wet oxidation method, particle size distribution was measured using the pipette method, and TP was determined by the molybdenum blue method [11]. The basic physico-chemical properties and the total concentration of $\mathrm{Pb}$ for two soil samples prior to immobilization are summarized in Table 1.

\section{Incubation Experiment}

The amendments included two pure chemical reagents, $\mathrm{H}_{3} \mathrm{PO}_{4}$ and $\mathrm{Ca}\left(\mathrm{H}_{2} \mathrm{PO}_{4}\right)_{2}$, as well as ground zeolite $(<0.2 \mathrm{~mm})$. Both $\mathrm{H}_{3} \mathrm{PO}_{4}$ and $\mathrm{Ca}\left(\mathrm{H}_{2} \mathrm{PO}_{4}\right)_{2}$ were added to $2.5 \mathrm{~kg}$ of soils in solution forms as the stabilizing additives at a 2.5:1 molar ratio of $\mathrm{P} / \mathrm{Pb}$ [12], and zeolite was added with a mass fraction of $1 \%(\mathrm{w} / \mathrm{w})$ [13]. The amended soils were thoroughly homogenized in large plastic containers prior to use. Soils without amendment were designated as control. All the treatments, including control, were performed in triplicate and incubated for two months in plastic containers with soil moisture content of $25 \%$ (Table 2).

\section{Assessment of $\mathrm{Pb}$ Bioavailability}

The TCLP test and the chemical partitioning of $\mathrm{Pb}$ were performed in accordance with the U.S. EPA protocol [14] and the sequential extraction procedure described by Li et al. [15], respectively, to evaluate the effectiveness of the immobilization treatment for these two contaminated urban soil types. The sequential extraction method [16] operationally defines the metals in four chemical forms: HOAc extractable, reducible, oxidizable, and residual fractions. The values of four fractions summed up were compared with total concentration to check the recovery, and the recovery values were found to be satisfactory (data not shown).

\section{Statistical Analysis}

A descriptive analysis was made with the SPSS V13.0 for Windows. A probability level of $p<0.05$ was considered as significantly different.

Table 1. Concentrations of $\mathrm{Pb}$ and physico-chemical properties for studied soils.

\begin{tabular}{|c|c|c|c|c|c|c|c|c|c|}
\hline \multirow{2}{*}{ Soil } & \multirow{2}{*}{$\begin{array}{c}\mathrm{Pb} \\
\mathrm{mg} / \mathrm{kg}\end{array}$} & \multirow{2}{*}{$\mathrm{pH}$} & \multirow{2}{*}{$\begin{array}{c}\mathrm{TP} \\
\mathrm{g} / \mathrm{kg}\end{array}$} & \multirow{2}{*}{$\begin{array}{l}\text { Organic matter } \\
\mathrm{g} / \mathrm{kg}\end{array}$} & \multirow{2}{*}{$\begin{array}{l}\mathrm{Fe} \\
\mathrm{g} / \mathrm{kg}\end{array}$} & \multirow{2}{*}{$\begin{array}{c}\mathrm{Mn} \\
\mathrm{mg} / \mathrm{kg}\end{array}$} & \multicolumn{3}{|c|}{ Particle size distribution (\%) } \\
\hline & & & & & & & $2-0.05 \mathrm{~mm}$ & $0.05-0.002 \mathrm{~mm}$ & $<0.002 \mathrm{~mm}$ \\
\hline $\mathrm{S} 1$ & 3805.5 & 8.4 & 0.48 & 93.7 & 90.5 & 856.3 & 62.7 & 24.4 & 12.9 \\
\hline $\mathrm{S} 2$ & 272.6 & 6.5 & 0.43 & 70.9 & 49.0 & 467.0 & 25.5 & 45.0 & 29.5 \\
\hline
\end{tabular}


Table 2. Soil treatments.

\begin{tabular}{|c|c|c|c|}
\hline \multirow{2}{*}{ Treatment } & \multirow{2}{*}{ Additive type } & \multicolumn{2}{|c|}{ Dose of additive $(\mathrm{g} / \mathrm{kg})$} \\
\cline { 2 - 4 } & & Soil 1 & Soil 2 \\
\hline $\mathrm{T} 1$ & $\mathrm{H}_{3} \mathrm{PO}_{4}$ & 4.5041 & 0.3226 \\
\hline $\mathrm{T} 2$ & $\mathrm{Ca}\left(\mathrm{H}_{2} \mathrm{PO}_{4}\right)_{2}$ & 5.3784 & 0.3852 \\
\hline $\mathrm{T} 3$ & $\mathrm{Ca}\left(\mathrm{H}_{2} \mathrm{PO}_{4}\right)_{2}+\mathrm{H}_{3} \mathrm{PO}_{4}$ & $2.2520+2.6892$ & $0.1613+0.1926$ \\
\hline T4 & Zeolite & 10 & 1 \\
\hline CK (control) & $/$ & $/$ & $/$ \\
\hline
\end{tabular}

\section{Results and Discussion}

\section{$\mathrm{Pb}$-Contaminated Soils}

The lead-contaminated soils used in this study were sourced from two locations impacted by distinct anthropogenic activities, namely iron smelting (Soil 1, S1) and historical use of leaded gasoline (Soil 2, S2). S1 was alkaline, sandy clay loam with a $\mathrm{Pb}$ concentration of $3,805.5 \mathrm{mg} / \mathrm{kg}$, while S2 was acidic and clay loam containing more than an order of magnitude lower $\mathrm{Pb}$ $(272.6 \mathrm{mg} / \mathrm{kg})$ than that of S1. Other physicochemical properties are detailed in Table 1. P amendments and zeolite application resulted in reduction and increase in soil $\mathrm{pH}$, respectively (data not shown).

\section{Leachability of $\mathrm{Pb}$ in the TCLP Extract}

The effects of amendments on the TCLP extractable $\mathrm{Pb}$ are shown in Fig. 1. The TCLP-Pb concentration for the soil spiked with $\mathrm{Pb}(\mathrm{CK}$, untreated soil) was $3.4 \mathrm{mg} / \mathrm{L}$ in $\mathrm{S} 1$ and $0.034 \mathrm{mg} / \mathrm{L}$ in $\mathrm{S} 2$, which are lower than the USEPA limit for soil (5 mg/L). Regardless of $\mathrm{H}_{3} \mathrm{PO}_{4}$ and/ or $\mathrm{Ca}\left(\mathrm{H}_{2} \mathrm{PO}_{4}\right)_{2}$, the phosphorus amendments significantly reduced the TCLP-Pb concentration in both soil types: in $\mathrm{S} 1$ by $91-93 \%$ and in $\mathrm{S} 2$ by $56-58 \%$. In comparison, the application of zeolite amendment significantly reduced the TCLP-Pb concentration in S1 (79\% reduction), whereas the TCLP-Pb concentration in S2 $(0.033 \mathrm{mg} / \mathrm{L})$ was not significantly reduced with the application of zeolite amendment.

In $\mathrm{S} 1$, the HOAc extractable $\mathrm{Pb}$ was significantly decreased by $82-83 \%$ after the application of phosphorus amendments and by $8.1 \%$ after the application of zeolite. In S2, however, the phosphorus amendment did not affect the concentration of HOAc-extractable $\mathrm{Pb}$, while the application of zeolite significantly reduced the HOAcextractable $\mathrm{Pb}$ by $26.9 \%$. The decreased $\mathrm{pH}$ in $\mathrm{S} 2$ could be one of the main factors responsible for the poor effectiveness of $\mathrm{Pb}$ immobilization by the phosphorus amendments. The soil $\mathrm{pH}$ has been shown to play an important role in increasing the cationic heavy metal retention to soil surfaces, which occurs via adsorption, inner sphere surface complexation, and/or precipitation [7, 17, 18]. Ruby et al. [19] also demonstrated that acidic $\mathrm{pH}$ decreases the bioavailability of $\mathrm{Pb}$ owing to the formation of anglesite and $\mathrm{Pb}$ jarosite, which are stable under the acidic gastric environment. Even though the effectiveness of $\mathrm{Pb}$ immobilization has been reported depending on the phosphate amendment, no significant differences were observed among $\mathrm{H}_{3} \mathrm{PO}_{4}$ and/or $\mathrm{Ca}\left(\mathrm{H}_{2} \mathrm{PO}_{4}\right)_{2}$ amendments in the current study. The efficiency of the phosphorus amendment in $\mathrm{Pb}$-contaminated soil has also been reported related to the type of soil and the nature and extent of the contamination [9].

\section{Changes in $\mathrm{Pb}$ Speciation}

The BCR extraction procedure was applied to evaluate the change of $\mathrm{Pb}$ speciation in soil after the incubation with phosphates and zeolite amendments. The proportion of residual $\mathrm{Pb}$ was expected to increase after the application of the amendments, and the results of $\mathrm{Pb}$ speciation in two soil types are summarized in Fig. 2. The distribution of various $\mathrm{Pb}$ speciation showed that the predominant fractions in $\mathrm{S} 1$ were the reducible and acid fractions, accounting for about $66.8 \%$ and $27.3 \%$ of total $\mathrm{Pb}$, respectively, and the application of the amendments significantly reduced the HOAc-extractable $\mathrm{Pb}$ (acid fraction) (Fig. 2a). However, all the amendments significantly increased the reducible

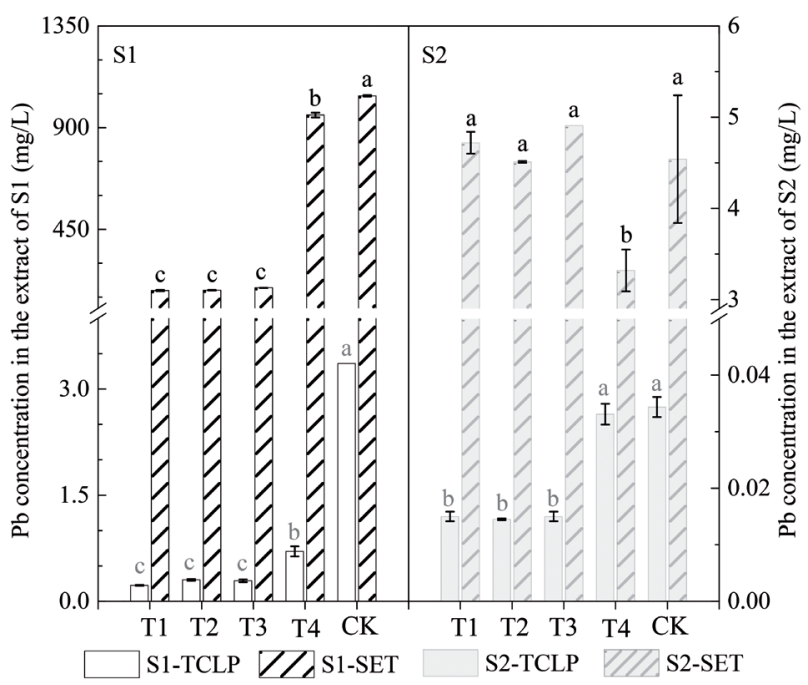

Fig. 1. TCLP extractable $\mathrm{Pb}$ and SET extractable $\mathrm{Pb}$ in two soils after the application of different amendments. Abbreviations are explained in Table 2. 


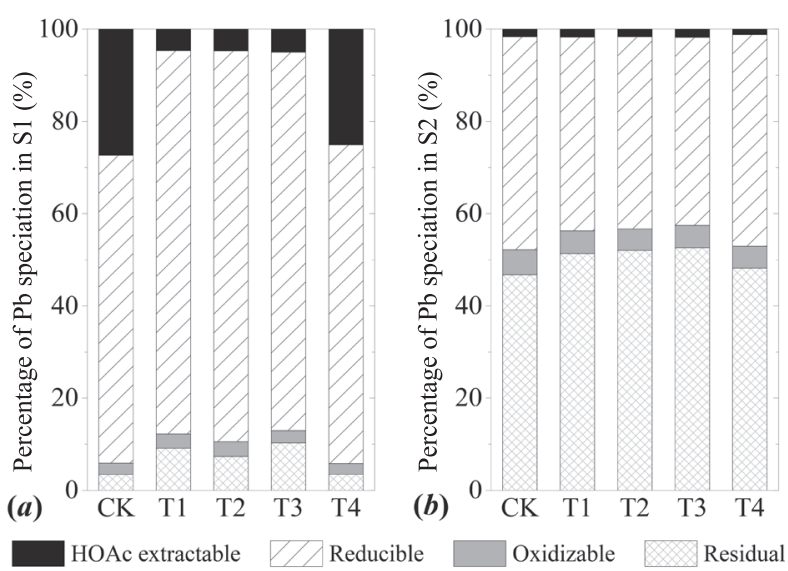

Fig. 2. Variations of $\mathrm{Pb}$ speciation in different fractions. Abbreviations are explained in Table 2.

fraction, and the addition of phosphates also increased the oxidizable and residual fractions. In comparison, the greatest proportion of $\mathrm{Pb}$ in $\mathrm{S} 2$ was associated with the reducible fraction $(49.1 \%)$, followed by the residual (43.8\%) (Fig. 2b). A very small proportion of $\mathrm{Pb}$ was found to be HOAc-extractable. The application of all the amendments significantly decreased the reducible and oxidizable fractions of $\mathrm{Pb}$ in $\mathrm{S} 2$, in contrast to $\mathrm{S} 1$, while all the amendments significantly increased the residual fraction of $\mathrm{Pb}$ as expected. Although the application of phosphorus amendments did not reduce the acid fraction of $\mathrm{Pb}$ in $\mathrm{S} 2$, a significant increase of the residual fraction of $\mathrm{Pb}$ was observed in both S1 and S2. On the other hand, the application of zeolite slightly decreased the acid fraction of $\mathrm{Pb}$ in both soil types.

\section{Conclusions}

Results demonstrated that the addition of phosphorus amendments could result in the transformation of nonresidual $\mathrm{Pb}$ to residual $\mathrm{Pb}$ in two contrasting urban soil types after a two-month incubation period. The addition of phosphorus amendments significantly reduced the TCLP-Pb concentration in both, whereas the efficiencies of the phosphorus amendments on the HOAc-extractable $\mathrm{Pb}$ were different, probably due to the different soil $\mathrm{pHs}$. The zeolite amendment diminished the TCLP-Pb in both soil types and the HOAc-extractable $\mathrm{Pb}$ in $\mathrm{S} 1$ (alkaline, high $\mathrm{Pb}$ ). Results suggest that the application of phosphorus-containing amendments to urban soils would be a useful strategy to induce $\mathrm{Pb}$ immobilization.

\section{Acknowledgements}

This research was supported by the National Natural Science Foundation of China (Grant Nos. 41271233, 51409106), a University of Macau Multi-Year Research Grant (MYRG2014-00112-FST), and the Macau Science and Technology Development Fund (FDCT/063/2013/A2).

\section{References}

1. CHENG H., LI M., ZHAO C., LI K., PENG M., QIN A., CHENG X. Overview of trace metals in the urban soil of 31 metropolises in China. J. Geochem. Explorat. 139, 31, 2014.

2. LI J.H., JIA C.J., LU Y., TANG S.F., SHIM H. Multivariate analysis of heavy metal leaching from urban soils following simulated acid rain. Microchem J. 122, 89, 2015.

3. RODR GUEZ-SEIJO A., ANDRADE M., VEGA F. Origin and spatial distribution of metals in urban soils. J. Soils Sediments. 2015. DOI: 10.1007/s11368-015-1304-2

4. LU Y., YIN W., HUANG L., ZHANG G., ZHAO Y. Assessment of bioaccessibility and exposure risk of arsenic and lead in urban soils of Guangzhou City, China. Environ. Geochem. Health. 33 (2), 93, 2011.

5. UN (United Nations). Department of Economic and Social Affairs, Population Division. World urbanization prospects: The 2014 revision, highlights (ST/ESA/SER.A/352). 2014.

6. LANPHEAR B.P., HORNUNG R., KHOURY J., YOLTON K., BAGHURST P., BELLINGER D.C., CANFIELD R.L., DIETRICH K.N., BORNSCHEIN R., GREENE T., ROTHENBERG S.J., NEEDLEMAN H.L., SCHNAAS L., WASSERMAN G., GRAZIANO J., ROBERTS R. Lowlevel environmental lead exposure and children's intellectual function: an international pooled analysis. Environ. Health Persp. 113 (7), 894, 2005.

7. JUHASZ A.L., GANCARZ D., HERDE C., MCCLURE S., SCHECKEL K.G., SMITH E. In situ formation of pyromorphite is not required for the reduction of in vivo $\mathrm{Pb}$ relative bioavailability in contaminated soils. Environ. Sci. Technol. 48 (12), $7002,2014$.

8. SHAHID M., XIONG T., MASOOD N., LEVEQUE T., QUENEA K., AUSTRUY A., FOUCAULT Y., DUMAT C. Influence of plant species and phosphorus amendments on metal speciation and bioavailability in a smelter impacted soil: a case study of food-chain contamination. J. Soils Sediments. 14 (4), 655, 2014.

9. HENRY H., NAUJOKAS M.F., ATTANAYAKE C., BASTA N.T., CHENG Z., HETTIARACHCHI G.M., MADDALONI M., SCHADT C., SCHECKEL K.G. Bioavailability-based in situ remediation to meet future lead $(\mathrm{Pb})$ standards in urban soils and gardens. Environ. Sci. Technol. 49 (15), 8948, 2015.

10. MIRETZKY P., FERNANDEZ-CIRELLI A. Phosphates for $\mathrm{Pb}$ immobilization in soils: a review. Environ. Chem. Lett. 6 (3), 121, 2008.

11. LI J., LU Y., YIN W., GAN H., ZHANG C., DENG X., LIAN J. Distribution of heavy metals in agricultural soils near a petrochemical complex in Guangzhou, China. Environ. Monit. Assess. 153 (1-4), 365, 2009.

12. XENIDIS A., STOURAITI C., PAPASSIOPI N. Stabilization of $\mathrm{Pb}$ and $\mathrm{As}$ in soils by applying combined treatment with phosphates and ferrous iron. J. Haz. Mat. 177 (1-3), 929, 2010.

13. GADEPALLE V.P., OUKI S.K., VAN HERWIJNEN R., HUTCHINGS T. Immobilization of heavy metals in soil using natural and waste materials for vegetation establishment on contaminated sites. Soil Sediment Contam. 16 (2), 233, 2007.

14. USEPA (United States Environmental Protection Agency). USEPA Method 1311 Toxicity Characteristic Leaching Procedure. USEPA, Washington, DC., 1992.

15. LI J., LU Y., SHIM H., DENG X., LIAN J., JIA Z., LI J. Use of the BCR sequential extraction procedure for the study of metal availability to plants. J. Environ. Monit. 12 (2), 466, 2010. 
16. RAURET G., F. LOPEZ-SANCHEZ J., SAHUQUILLO A., RUBIO R., DAVIDSON C., URE A., QUEVAUVILLER P. Improvement of the BCR three step sequential extraction procedure prior to the certification of new sediment and soil reference materials. J. Environ. Monit. 1 (1), 57, 1999.

17. APPEL C., MA L. Concentration, $\mathrm{pH}$, and surface charge effects on cadmium and lead sorption in three tropical soils. J. Environ. Qual. 31 (2), 581, 2002.
18. SU X., ZHU J., FU Q., ZUO J., LIU Y., HU H. Immobilization of lead in anthropogenic contaminated soils using phosphates with/without oxalic acid. J. Environ. Sci. 28, 64, 2015.

19. RUBY M.V., DAVIS A., SCHOOF R., EBERLE S., SELLSTONE C.M. Estimation of lead and arsenic bioavailability using a physiologically based extraction test. Environ. Sci. Technol. 30 (2), 422, 1996. 